\title{
Effect of Scholarships on Students' Social Development at University Level
}

\author{
* Shabeena Shaheen, PhD Scholar \\ ** Dr. Ziarab Mahmood, Assistant Professor \\ *** Dr. Nazir Haider Shah, Assistant Professor (Corresponding Author)
}

\begin{abstract}
The major purpose of the study was to measure the effect of scholarships on students' social development at the university level. The study was descriptive, and the survey method was applied for the collection of data. The population consisted of all teachers and students of public and private universities of Rawalpindi and Islamabad. The total population of teachers in the public and private universities were 4073 and students were 101968. A stratified random sampling technique was applied for selecting the study sample. The researcher selected 525 teachers from public and private universities as well as 900 students from public and private universities. The researcher developed two questionnaires using a five-point Likert scale on the foundation of related literature and with the help of the supervisor. The validity of the instruments was checked by two experts in the field. The reliability of these instruments was determined through Cronbach's alpha which was 0.832. Mean, standard deviation, $t$-test, and regression analysis were used for analyzing the data. It was found that scholarships are available at the public and private sector universities. It was also found that there was a significant effect of scholarships on students' development. Therefore, it is recommended that scholarships may be spread on the university website, to guarantee students successful learning, higher education institutions will have to meet the challenges of student's problems.
\end{abstract}

Keywords: Scholarships, students' development, Social development, University level Introduction

Scholarships are financial rewards provided to students based on academic achievements and commitments. Many scholarships are awarded based on merit. However, some people also consider financial needs. Universities, governments, and companies can provide cash for scholarships in a slightly benevolent manner (Flinn, 2010). Scholarships enable students to continue to receive higher education through financial aid and assist students to continue their studies or further study. All scholarships are issued according to the sponsor's standards and wishes. The scholarship is effective for students, reduces the cost of education, and enables students to focus on education instead of parttime work. Scholarships can be used to fund students' advancement and degree admissions, as well as student performance. The motivation and confidence to work for a good future (Heller, 2002).

One of the main points is that scholarships cannot alone make sure the development of students, scholarships generally do not meet the full cost of tuition fees, even when a student can accrue multiple forms of public and private aid. Depending on a students' financial and educational background, maybe it needed any other forms of support to succeed in education. Universities prefer those students who get a scholarship. Getting a scholarship in university is a big deal and maximum universities are looking forward to adding students who will be helpful suppliers to their student body. A merit-based scholarship confirms that you are a proficient student who would be a great addition to the institute (Goodman, 2008)

Higher education and financial assistance must be approachable to meet student needs and to provide financial assistance for all students. Financial aid states to any funding or scholarships, award, loans, donations, allowances, to help student access to complete and further education. Merit-based

\footnotetext{
* Department of Education, Mohi-Ud-Din Islamic University, Nerian Sharif, AJ\&K Email: shabeena.mz@gmail.com

** Department of Education, Mohi-Ud-Din Islamic University, Nerian Sharif, AJ\&K Email: ziarabmahmood@gmail.com

*** Department of Education, Mohi-Ud-Din Islamic University, Nerian Sharif, AJ\&K Email: nazirshah786@gmail.com
} 
financial assistance granted for special talents, such as sports, leadership potential as well as including ethnicity, religious background, or group association. As the name appears need-based financial assistance is granted based on a students' need which provides institutions by the process of the student aid application (Trainor, 2002).

The institutes play a vital role in the personality development of students. The institute serves as the source of the student's social and nurturing mental health and makes necessary changes to the students' personalities to prosecute a responsible citizen. The development of personality is substantial as this time and overall development are necessary for their survival in this competitive world and to withstand in the race. Each person reflects a diverse character and personality, whose character can be polished, refined, and developed (Heyne, Wilkins \& Anderson, 2012).

Braskamp and Ward (2006) pointed out that development is a process in which individuals will realize their shortcomings and potentials, thereby developing self-esteem, becoming more confident, self-reliant, cooperating and tolerant of others, and gaining new knowledge through cooperation with others. Others actively participate in the economic, social, and political development of their communities to achieve their goals.

Development models are usually divided into three categories, including the physical, cognitive, and socio-physical fields, which involve biological changes that occur over time. These include changes in body size, proportions, appearance, motor skills, physical health, etc. Cognitive domains include changes in intelligence, skills, thinking, intelligence, creativity, attention, memory, language, etc. This is related to changes in students. Relationships, feelings, emotions, values, beliefs, and personality with others (Dhillon, Gowan \& Wang, 2006).

Social development is an important aspect of student development. It is the ability to establish positive and pleasant relationships with others. Social development includes learning values, knowledge, and skills so that learners can effectively connect with others and contribute to the family, school, and community positively. Through relationships with others and an evolving understanding of social norms, values, and expectations, students can build a sense of identity (who they are). With the development of students' social skills, they not only learn how to respond appropriately in various situations, but also play a role in establishing interpersonal relationships (Colby \& Sullivan, 2009).

\section{Objectives}

1. To explore the availability of scholarships at the university level.

2. To measure the effect of scholarships on the students' development.

3. To compare the opportunities of scholarships in public and private sector universities.

\section{Research Questions}

1. What are the available scholarships in higher education?

2. What are the effects of scholarships on the students' social development?

3. What are the opportunities for scholarships in public and private sector universities?

\section{Review of Literature}

\section{Scholarships}

The scholarship defined by Boyer aims to study innovative methods and effective practices that focus on the actions taken by students to improve skills and spread knowledge. Boyer's second framework is called "Discovery Scholarship", which focuses on how scholars create new knowledge. The creation of new knowledge can be carried out through an environment where students exercise leadership skills, including work organized by students and campus activities. The third frame of the scholarship determines the scholarship application. Boyer defines it as the act of applying knowledge to solve real-world problems, and the third framework of scholarship determines the scholarship to be applied for. Boyer defined it as the act of applying knowledge to solve practical problems. For example, the concept of "applied learning" is closely related to the work of student employee supervisors. In the practice of campus activities, knowledge is applied in real-life every day. Finally, his framework is called "integration scholarship", which brings new understanding through thought integration. The role of student organization consultants in mentoring, coaching, or mentoring practice with student leaders can usually help them understand the meaning of these experiences and connect learning from different student experience areas (Boyer, 1990).

Scholarship is the use of systematic methods to acquire knowledge through intellectual inquiry. The scholarship includes disseminating this knowledge through publications, lectures (oral 
and audiovisual), professional practice, and applying this new knowledge to various ways of enriching social life (Isaac Abraham, 1993).

Scholarships are a financial aid to students seeking education. Scholarships are issued on a different basis. Usually, students need financial assistance to achieve their educational goals. The scholarship method is to obtain knowledge through indigenous surveys. The scholarship spreads knowledge through various methods, including lectures, publications, professional knowledge, and the application of new knowledge to social development. Scholarships provide many people with the opportunity to receive an education. Without the help of external resources, students may find it difficult to enter the labor market and become important members of society. In this way, scholarships provide opportunities for all talented students who cannot go to university due to financial constraints (Perna \& Kishkentayeva, 2014).

Scholarships are funded by students based on the purpose of university education, their academic achievements, or other criteria that may include financial needs. There are different types of scholarships, the two most common are scholarship-based and need-based scholarships. The donor or department sets the selection criteria, and the donor clearly describes how to use the money. These funds are paid directly by the university and are used to pay for tuition, books, room and board, food, and other expenses related to student education. Numerous studies have confirmed that excellent scholarships have a significant impact on local students' college admissions, course selection, and academic performance (Fennely, 2003).

Career benefits. Receiving prestigious or merit-based scholarships can make students more attractive. Employers who understand the competitive nature of scholarships will consider this an achievement. Generally, performance-based scholarships prove to prospective employers that students have extraordinary abilities in the academic, sports, or artistic fields. Competitive scholarships are achievements worthy of being listed in their resumes, which can help them stand out when looking for a job and help them achieve their desired career (Mutie, \& Ndambuki, 2000).

This scholarship program support individuals who are passionate about improving their knowledge and to sustain a deep understanding of their abilities such as academic skills, talents, extra composition activities. The concern is to raise and to improve the financial needs for each family of the students. This is the help benefits that our government gives to the students who cannot afford or have an insufficient amount of money to the tuition fee of their school or university.

Ali and Ahmad (2011) pointed out that the rapid economic development of a country depends on the provision of education and skilled manpower. Education will not only produce new ideas and abilities in individuals, but also new ideas. It has also accelerated the pace of technological transformation. For economists, higher education is seen as preparing people to make better choices and providing them with the skills and qualities to lead a better life. Besides, it will contribute to the economic development of the country's society. A person's development is viewed as a series of development tasks that reflect changes in personal thoughts, feelings, values, and relationships with others (Chickering and Reiser, 1993).

Scholarships will become a tool to promote successful career decisions (Borrow, 1993). Scholarships can fill the gap. Scholarship assistance can support the gap between high-income and low-income students who may not qualify for need-based scholarships and do not meet the criteria for performance-based scholarships (Dhillon, Gowan \& Wang, 2006).

Participation Theory Scholarship This theory was originally used by Palmer and Zajonc (2010) and later expanded by Dhillon \& Wang (2006) and McInnis, (2001). The theory points out that other forms of scholarship should be expanded and deepened to create the possibility of citizens participating in higher education. It can also be called a participation scholarship. Therefore, by emphasizing "scholarship" rather than "learning", scholarships participating in research propose a series of practices covering all aspects of the traditional functions of higher education (Omeje \& Abugu, 2015).

\section{Student Development}

The latest developments in this field provide some important new methods for exploring human resource development (HRD) methods. Capacity development is such a concept or term. Traditionally, capacity development is also understood as human resource development, but its development is much more than that, because it is a larger concept, because it not only refers to the acquisition of skills, but also refers to the ability to use skills (Sharkin, 2004). 
A person's development is related to changes that can be described in a theoretical framework. Individuals change because their development enables them to create a sense of self. It is considered to have a good foundation and stability, especially in the adolescence of student life. The application of development theory knowledge is the basis for analyzing the behavior changes of poor students during their growth. The application of student development theory stems from the findings of how people develop. The theory of human-environment interaction with Chickering as its main supporter believes that individual personality is affected by the interaction between it and the environment. Interaction helps them develop their lifestyle. Because different developmental processes will lead to shaping a person in different environments, when students grow up from different environments and later placed in different environments, they will have different experiences. Even though the environment plays a broad role in shaping a person, other factors can explain student development, especially poor parenting caused by extreme poverty (Chickering, 1993).

\section{Social Development}

Social development refers to the process by which children learn to interact with others around them. As they develop and perceive their personalities in the community, they will also acquire the skills to communicate with others and process their behavior. Social development usually refers to how children develop friendships and other relationships, and how children deal with conflicts with peers. Vygotsky believes that this lifelong development process depends on social interaction, and social learning leads to cognitive development. This phenomenon is called the near-end development zone. Vygotsky describes it as "the distance between the actual level of development determined by an independent problem-solving solution and the potential level of development determined through a problem-solving solution under the guidance of an adult or in cooperation with a more capable partner" (Sharkin, 2004).

\section{Methods and Materials}

In this study scholarships have taken as an independent variable and whereas student social development is a dependent variable. The study was carried out the effects of scholarships on students' social development at the university level in public and private universities of Rawalpindi and Islamabad. Therefore, the study was descriptive, and the survey method was applied for the collection of data. The population consisted of all teachers and students of public and private universities of Rawalpindi and Islamabad. The total population of teachers in the public and private universities was 4073 and students were 101968. Six universities were delimited to the study. A stratified random sampling technique was applied for selecting the study sample. For this purpose, the researcher used a proportionate stratified random sampling technique. The researcher selected 525 teachers from public and private universities as well as 900 students from public and private universities (Gay, 2009). The researcher developed two questionnaires using a five-point Likert scale on the foundation of related literature and with the help of the supervisor. The first portion of the instrument was based on demographic variables, the second portion has consisted of the effects of scholarships, and the last portion of the instrument based on social development. The validity of the instruments was checked by two experts in the field. Their suggestions were incorporated into the questionnaire. It was also validated by experts; the reliability of these instruments was determined through Cronbach's alpha as a measure of the internal consistency of items. The reliability of the tool was 0.832 . SPSS was used for statistical analysis. Mean, standard deviation was used to find out the availability of scholarships. The linear Regression analysis was used to measure the effect of scholarship on students' social development. The t-test was used to compare the views of the teacher and students regarding scholarships.

\section{Analysis}

\section{Table 1}

Availability of scholarships at the university level

\begin{tabular}{lllr} 
Student Support Services & N & Mean & Std.Deviation \\
\hline Merit-based scholarships & 525 & 5.50 & 2.129 \\
Need-based scholarships & 525 & 5.90 & 2.270 \\
\hline
\end{tabular}

The table shows the average and standard deviation of variables about scholarships. The table shows that need-based scholarships are greater than performance-based scholarships. Need-based scholarships are better than performance-based scholarships. 
Table 2

Availability of scholarships at the university level

\begin{tabular}{llrr} 
Student Support Services & N & Mean & Std.Deviation \\
\hline Merit-based scholarships & 900 & 5.66 & 2.258 \\
Need-based scholarships & 900 & 5.82 & 2.327
\end{tabular}

The above table describes the mean and standard deviation of variables regarding scholarships. The table shows that need-based scholarships are greater than performance-based scholarships. Providing need-based scholarships is better than performance-based scholarships

Table 3

Model summary effect of scholarships on student's social development

\begin{tabular}{lcccc}
\hline Model & $\mathrm{R}$ & $\mathrm{R}$ Square & Adjusted R Square & Std. Error of the Estimate \\
\hline 1 & .433 & .188 & .186 & 12.224 \\
\hline a. Predictors: (Constant), scholarships & & &
\end{tabular}

a. Predictors: (Constant), scholarships

The table indicates the model summary effect of scholarships on student's social development. As a result, the correlation is .433 and $\mathrm{R}$ is .188. There is a moderate relationship between scholarship and social development.

Table 4

ANOVA summary effect of scholarships on student's social development

\begin{tabular}{llrrrrr} 
Model & & Sum of Squares & df & Mean Square & F & Sig. \\
\hline 1 & Regression & 18055.702 & 1 & 18055.702 & 120.836 & .000 \\
& Residual & 78148.290 & 524 & 149.423 & & \\
& Total & 96203.992 & 525 & & & \\
\hline
\end{tabular}

a. Dependent Variable: Social development

a. Predictors: (Constant), scholarships

ANOVA summary of the effect of scholarships on student's social development demonstrated in the table. This table shows that the regression equation is significant $\mathrm{F}(1,524)=120.136, p=.000$, therefore scholarships are a significant predictor of social development.

Table 5

Coefficients summary effect of scholarships on student's social development

\begin{tabular}{llccccc}
\hline & \multicolumn{7}{c}{ Standardized } & & \\
Model & & \multicolumn{2}{c}{ Unstandardized Coefficients } & Coefficients & $\mathrm{t}$ & Sig. \\
\hline \multirow{2}{*}{1} & $\mathrm{~B}$ & Std. Error & Beta & & \\
& (Constant) & 44.740 & .946 & & 47.286 & .000 \\
& scholarships & .169 & .015 & .433 & 10.993 & .000 \\
\hline
\end{tabular}

a. Dependent Variable: Social development

This table demonstrates the coefficient summary of the model. It reveals that the value of coefficient scholarships was. 169 , its $t$ value is 10.993 which is significant at the .05 level as $p=.000 \mathrm{It}$ means there was a significant difference between scholarships and student's social development.

Regression analysis Student "Effect of scholarships on Student's social development" regarding students' scale.

Table 6

Model summary Effect of scholarships on student's social development

\begin{tabular}{lcccc}
\hline Model & $\mathrm{R}$ & $\mathrm{R}$ Square & Adjusted R Square & Std. Error of the Estimate \\
\hline 1 & .418 & .175 & .174 & 12.995 \\
\hline
\end{tabular}

a. Predictors: (Constant), scholarships

The table revealed a moderate relationship between scholarships and student's social development. The correlation is .418 and $\mathrm{R}$ is .175 .

Table 7

\begin{tabular}{|c|c|c|c|c|c|c|}
\hline Model & & Sum of Squares & Df & Mean Square & $\mathrm{F}$ & Sig. \\
\hline \multirow[t]{3}{*}{1} & Regression & 32118.759 & 1 & 32118.759 & 190.193 & $.000^{\mathrm{b}}$ \\
\hline & Residual & 151649.253 & 898 & 168.874 & & \\
\hline & Total & 183768.012 & 899 & & & \\
\hline
\end{tabular}

a. Dependent Variable: Social development

b. Predictors: (Constant), scholarships 
The table shows the ANOVA summary of the effect of Scholarships on Student's social development. This table shows that the regression equation is significant $\mathrm{F}(1,898)=190.193$, $\mathrm{p}=.000$, hence, is scholarships a significant predictor of social development.

Table 8

Coefficients summary effect of scholarships on student's social development

\begin{tabular}{|c|c|c|c|c|c|c|}
\hline \multirow[b]{2}{*}{ Model } & & \multirow{2}{*}{\multicolumn{2}{|c|}{ Unstandardized Coefficients }} & \multicolumn{2}{|l|}{ Standardized } & \multirow[b]{2}{*}{ Sig. } \\
\hline & & & & Coefficients & $\mathrm{t}$ & \\
\hline \multirow{3}{*}{1} & & $\mathrm{~B}$ & Std. Error & Beta & & \\
\hline & (Constant) & 42.443 & 1.281 & & 33.122 & .000 \\
\hline & scholarships & 1.449 & .105 & .418 & 13.791 & .000 \\
\hline
\end{tabular}

a. Dependent Variable: Social development

This table demonstrates the coefficient summary effect of scholarships on student's social development. It reveals that the value of coefficient scholarships was.1.449 its t value is 13.791 which is significant at the .05 level as $\mathrm{p}=.000$ It means there was a significant difference between scholarship and student's social development.

Table 9

Mean difference between public and private sector teachers regarding scholarships

\begin{tabular}{llllllll}
\hline Edu sec & $\mathrm{N}$ & Mean & Std. Deviation & $\mathrm{df}$ & $\mathrm{f}$ & $\mathrm{T}$ & Sig \\
\hline Public & 350 & 57.35 & 1.2833 & 523 & .688 & 2.105 & .036 \\
Private & 175 & 54.65 & 1.2952 & & & & \\
\hline
\end{tabular}

The table shows the mean difference between public and private university teachers' perceptions of scholarships. The mean of teachers in the public sector is 57.35 , while the mean of teachers in the private sector is .54 .65 . The mean of teachers in the public sector is greater than the number of teachers in the private sector. When the P-value is greater than 0.05 , the mean difference of 2.7 is statistically significant. This means that when it comes to scholarships, teachers in the public sector have better insights than teachers in the private sector.

Table 10

Mean difference between Public and Private sector Students regarding scholarships

\begin{tabular}{lllllllr}
\hline Edu sec & $\mathrm{N}$ & Mean & Std. Deviation & df & f & T & Sig \\
\hline Public & 500 & 43.54 & 19.869 & 898 & .197 & 15.480 & .000 \\
Private & 400 & 22.73 & 18.910 & & & & \\
\hline
\end{tabular}

The table indicates the mean difference of the between public and private universities student opinions regarding scholarships. The mean of the public sector was 43.54and was private-sector students 22.73. The mean of private-sector students is greater than the public sector students. This mean difference i.e. 20.81 is statistically significant as $\mathrm{P}$ is less than .05 . It means that public sector student sector opinion regarding scholarships is better than public sector students regarding scholarships.

\section{Discussion}

The main purpose of the study was to measure the effect of scholarships on students' social development at the university level. The first objective of the study was to explore the availability of scholarships at the university level. It was found that there are different scholarships are available in higher education. Similar studies have been done by different researchers like Goodman (2008); Hurlock (2002). Jain (2013) found that scholarships are available in higher education institutions like universities. In the consequent little difference exists between merit-based scholarships and needbased scholarships. Need-based scholarships are available than merit-based scholarships.

The second objective of the study was to measure the effect of scholarships on the students' social development. The study found that scholarships have a positive effect on student social development. Similar studies have been conducted by Hurlock (2002); Sharkin (2004); Omeje and Abugu (2015).; Voss, Gruber \& Smzigin (2007). They had found that the scholarships had a significant effect on student's social development because it is observed when a student gets any kind of scholarship then he feels good and different from their fellows.

The third objective of the study was to compare the opportunities of scholarships in public and private sector universities. It was found that the scholarships are available in both the universities. These scholarships have a positive effect on student social development. The public universities 
student viewpoint is higher than private-sector students regarding need-based scholarship are available than merit-based scholarship.

\section{Conclusions}

1. It is concluded that scholarships (need and merit-based) are available at the public and private sector universities.

2. It is also concluded that there was a significant effect of scholarships on students' social development.

3. It is further concluded that more scholarships are available in the public universities as compare to private universities.

\section{Recommendations}

1. It was found that scholarships (need and merit-based) are available at the public and private sector universities so, it is recommended that Scholarships may be spread on the university website and disseminate through social media so that the students may get better information and can apply for scholarships. Move over, The University should provide the student with equal access to scholarships.

2. It was found that there was a significant effect of scholarships on students' social development therefore, the Government and Higher Education Commission may introduce more scholarships for needy students to cope with the needs of students.

3. It was found that more scholarships are available in the public universities as compare to private universities. So, it is recommended that the Higher Education Commission may provide scholarships to private universities

\section{References}

Ali, A., and Ahmad, I. (2011). Key factors for determining students' satisfaction in distance learning courses: A Study of Allama Iqbal Open University. Contemporary Educational Technology, 2(2), 118-134.

Borrow, H. (1993). Career Guidance for new age. Boston: Houghton Mifflin Company.

Boyer, E. L. (1990). Scholarship reconsidered: Priorities of the professoriate. San Francisco, CA: Jossey-Bass.

Braskamp, L.A., and Ward, K. (2006). Putting Students First: How Colleges Develop Students Purposefully. San Francisco CA: Jossey-Bass/Anker Publishing.

Chickering, A. W., and Reisser, L. (1993). Education and identity. (2nd Ed.) Ed. San Francisco: Jossey-Bass.

Colby, A., and Sullivan, W. M. (2009). 'Strengthening the Foundations of Students' Excellence, Integrity, and Social Contribution'. Association of American Colleges and Universities.

Dhillon J., Mc Gowan M. \& Wang H. (2006). What do we mean by student support? Staff and students' perspectives on the provision and effectiveness of support students. University of Wolverhampton Educational Evaluation and Policy Analysis, 32(2): 143-165.

Dhillon J., Mc Gowan M. \& Wang H. (2006). What do we mean by student support? Staff and students' perspectives on the provision and effectiveness of support students. University of Wolverhampton Educational Evaluation and Policy Analysis, 32(2). 143-165.

Goodman, J. (2008). "Who merits financial aid? Massachusetts' Adams Scholarship." Scholarship. Journal of Public Scholarships in Pakistan, 92(10-11), 2121-2131.

Heller, D. E. (2012). "Making College a Priority: Promising Practices and Strategies." Testimony before the U.S. Senate Committee on Health, Education, Labor, and Pensions.

Heyne L., Wilkins V., \& Anderson L. (2012). Social inclusion in the lunchroom and on the playground at school. Social Advocacy and Systems Change Journal, 3(2), 54-68.

Hurlock, R. L. (2002). Introduction to Guidance and Counselling in Schools and colleges. New Jersey: Education Upper Saddle Publishers.

Jain, P. (2013). A paradigm shift in the 21st century academic libraries and librarians: Prospectus and opportunities. European Journal of Academic Research, 1(3), 133- 147.

McInnis, C. (2001). Researching the first-year experience: Where to from here? Higher Education Research and Development, 20(2), 567-578.

Mutie, E. K., \& Ndambuki, P. (2000). Guidance and counseling for secondary school and a case of Sotik District, Bomet County, Kenya. Journal of Education and Practice 4(3), 345-344. 
Omeje, A. N. and Abugu, S. O, (2015). The Impact of Scholarships on Students' Academic Performance: A Case of Tertiary Institutions in Enugu State, Nigeria. Bulletin of Business and Economics, 4(2), 93-104.

Palmer, P.J., Zajonc, A. (2010). The heart of higher education: a call to renewal, San Francisco CA: Jossey-Bass; John Wiley.

Perna, M. Kishkentayeva. (2014). promoting human capital development: a typology of international scholarship programs in higher education. Educational Researcher., 43 (2) 63-73.

Sharkin, B. S. (2004). College counseling and student retention: Research findings and implications for counseling centers. Journal of College Counseling, 7(3), 99-108.

Trainor, R. (2002). The student services research project: effective approaches to retaining students in higher education. Report from the Ministry of Lifelong Learning, Further and Higher Education. London: Greenwich Press university campus: Personal safety practices, beliefs, and attitudes of female University of California Office of the President.

Voss, R., Gruber, T., \& Smzigin, I. (2007). Service quality in higher education: The role of students expectations. Journal of Business Research, 23(4), 949-959. 